\title{
Yagder serratus, a new eyeless weevil from Mexico and the non-monophyly of Brachycerinae, the evolutionary twilight zone of true weevils (Coleoptera: Curculionidae)
}

\author{
Vasily V. GREBENNIKOV ${ }^{1)} \&$ Robert S. ANDERSON ${ }^{21}$ \\ 1) Canadian Food Inspection Agency, 960 Carling Ave., Ottawa, ON, K1A 0Y9, Canada; e-mail: vasily.grebennikov@canada.ca \\ ${ }^{2)}$ Beaty Centre for Species Discovery, Canadian Museum of Nature, PO Box 3443, Station D, Ottawa, ON K1P 6P4, Canada; \\ e-mail: randerson@nature.ca
}

\begin{abstract}
Accepted:
$8^{\text {th }}$ September 2021

Published online:

$22^{\text {nd }}$ September 2021
\end{abstract}

\begin{abstract}
We describe and illustrate a new eyeless weevil, Yagder serratus gen. \& sp. nov., based on a single adult female collected by sifting forest leaf litter in Mexico. A phylogenetic analysis of 39 terminals and 2679 aligned positions from three DNA fragments places the new species into the subfamily Brachycerinae (as incertae sedis) and outside the highly diversified clade of 'higher' true weevils. Neither Brachycerinae, nor its tribe Raymondionymini traditionally uniting most eyeless weevils, are monophyletic unless the latter is limited to a Mediterranean core group. Both these taxa are taxonomic dumping-grounds likely containing species-poor sisters of species-rich clades. When resolved, the subfamily Brachycerinae will be likely split into two or more species-poor deeply-divergent subfamilies.
\end{abstract}

Key words. Coleoptera, DNA barcode, ITS2, 28S, phylogeny, forest litter, species discovery

Zoobank: http://zoobank.org/urn:lsid:zoobank.org:pub:B7C0C54B-7605-48C7-A568-7DD2FAB45D8A

(C) 2021 The Authors. This work is licensed under the Creative Commons Attribution-NonCommercial-NoDerivs 3.0 Licence.

\section{Introduction}

Large portions of the Tree of Life remain phylogenetically uncharted. This is particularly true for yet undescribed small-bodied dwellers of cryptic habitats in remote and/or biodiverse areas of the Globe. Discovery of such organisms is often akin to solving an equation with two unknowns: placing the new puzzling terminal into its unexplored phylogenetic neighbourhood. Inadequately known, likely deeply-divergent and species-poor clades are often artificially united into non-monophyletic 'basal' taxa. These assemblages of unrelated and unresolved clades are often referred to as 'twilight zones' (LOPARDO \& Hormiga 2015, BAI et al. 2016) or 'dumping grounds'. Such 'twilight zones' unite organisms lacking synapomorphies of the well-established and species-rich clades, thus simultaneously likely non-monophyletic. When relationships among constituents are finally resolved, new higher taxa are likely to emerge from these taxonomic dumping grounds. Prominent arthropod examples include pteromalid chalcid wasps (Heraty et al. 2013) and Endeostigmata mites (KLIMOv et al. 2018).
Our paper is pivoted on a discovery of a new weevil from Mexico (Figs 1-2) and its phylogenetic placement. Weevils (Curculionidae) are the globally distributed clade sister to the much smaller family Brentidae (MARVALDI et al. 2002, Haran et al. 2013, Gillett et al. 2014, GunTER et al. 2016, SHIN et al. 2017). With $>50,000$ named species, Curculionidae is the second largest animal family, second only to rove-beetles (Staphylinidae). The basal-most dichotomies within the weevils are notoriously unresolved. This ambiguity is reflected in the continuous existence of the non-monophyletic subfamily Brachycerinae, which forms the twilight zone of true weevils. This artificial subfamily contains organisms most similar, or perhaps most closely related, to our new eyeless Mexican weevil, and therefore is highlighted, alas unresolved, in the present paper.

The hinge of our study is a single adult weevil (Figs 1-2) sampled in 2019 by sifting forest litter on a mountain ridge at $1370 \mathrm{~m}$, some $5 \mathrm{~km} \mathrm{SW}$ of the town of Hueytamalco, Puebla, SE Mexico (Fig. 3). The external morphology of this beetle and its DNA barcode (HEBERT et al. 2003) were notably unlike most of what we have 
seen in weevils globally. Specifically, the specimen was $3.8 \mathrm{~mm}$ in body length (without rostrum), slender and parallel-sided, with a straight and long rostrum, with head deeply retracted into pronotum, with deeply punctate and rugged dorsal surface of pronotum and elytra, and with sharp and large serrations along the elytral contour in dorsal view (Fig. 1). Most notably, the specimen was completely eyeless (Fig. 2D). Its overall appearance did not recall known eyeless species scattered among 'higher' weevils from Central America or from elsewhere (OSELLA 1979, Howden 1992, Morrone \& Hlaváč 2018). The specimen might perhaps be best compared with some eyeless Brachycerinae, although it is at least twice greater in body length than their majority (Fig. 4). After preliminary morphological evaluation we concluded that this Mexican weevil is unlikely to belong to any subfamily of the higher Curculionidae, but likely to Brachycerinae.

This preliminary taxonomic solution was, however, unsatisfactory. Brachycerinae are notoriously non-monophyletic. As presently delimited (OBERPRIELER 2014), the subfamily is a classical wastebasket taxon accommodating all true weevils (= members of monophyletic Curculionidae) outside of the monophyletic (DAVIs 2017, SHIN et al. 2017) and species-rich core of the family. This latter consists of two sister clades (SHIN et al. 2017): one is formed by Dryophthorinae + Platypodinae (with or without monophyletic Bagoinae) and another a much greater monophylum of subfamilies, itself consisting of two sister clades: the CEGH clade and the CCCMS clade. Both CEGH and CCCMS clades (first defined by GUNTER et al. 2016) are collectively referred to as 'higher' Curculionidae (SHIN et al. 2017) and accommodate about four fifths of extant weevils. The CEGH clade consists of Cyclominae, Entiminae, Gonipterini, and Hyperini, while the larger CCCMS clade is formed by Curculioninae, Conoderinae, Cossoninae, Molytinae and Scolytinae (with at least some of these subfamilies non-monophyletic). This phylogenetic pattern consistently re-emerges in independent analyses (HARAN et al. 2013, GiLletT et al. 2014). All weevils not fitting into these major clades are taxonomically assigned to the family's twilight zone, the non-monophyletic subfamily Brachycerinae.

The exact number of unrelated clades of weevils currently assigned to Brachycerinae is impossible to estimate, with three (SHIN et al. 2017) being likely the lowest number. Circumstantial evidence (OBERPRIELER 2014) suggests that this number might be higher, as more members of this subfamily gradually become available for phylogenetic analyses. Significantly for our purpose, Brachycerinae include a number of eyeless in deep soil living taxa, whose monophyly and sister-group relationships are far from certain. At this stage it became obvious to us that to place our eyeless Mexican weevil into the phylogenetic context, we must focus on Brachycerinae, particularly its eyeless members.

The concept of the subfamily Brachycerinae has varied widely and became stabilized (alas unavoidably temporarily) only recently (OBERPRIELER 2014). This subfamily formally consists of about 95 genera grouped in seven tribes (OBERPRIELER 2014): Brachycerini, Cryptolaryngini, Erirhinini (including the genus Ocladius Schönherr, 1825 and its relatives often treated separately from the rest of Erirhinini), Himasthlophallini, Tanysphyrini, Myrtonymini and Raymondionymini. The total number of Brachycerinae species is about 1,200 (OBERPRIELER et al. 2007) or 1,350 (OBERPRIELER 2014), which is merely $2-3 \%$ of the hyper-diverse Curculionidae. While most Brachycerinae are fully eyed and often volant, some are exclusively subterranean, eyeless, wingless, and are found in widely separated parts of the globe (Fig. 3). When eyeless, Brachycerinae are predominantly very small and slender beetles, averaging about $1-3 \mathrm{~mm}$ in body length (excluding rostrum and head capsule; as with our species, the latter is often deeply retracted into the pronotum and is not apparent when viewed from above; Fig. 4). Four of the seven tribes of Brachycerinae contain eyeless species, and three of them exclusively so. The tribe Erirhinini contains one such genus, Absoloniella Formánek, 1913 (Fig. 4), with five exceptionally poorly known Mediterranean species (CALDARA \& Colla 2018). The tribe Himasthlophallini consists of microphthalmic Himasthlophallus flagellifer Egorov \& Zherikhin, 1991 (Fig. 4) from the Russian Far East (Fig. 3) with an eye formed of three ommatidia (Fig. 5F). The tribe Myrtonymini consists of two genera: Myrtonymus Kuschel, 1990 (Fig. 4) with six species in New Zealand, Australia and New Caledonia, as well as the monotypic Hexonymus Kuschel, 2014 from Australia (Fig. 3). Myrtonymini are the smallest weevils known, all seven species less than 1 $\mathrm{mm}$ in body length (excluding rostrum, KusCHEL 2014). The genus Absoloniella and both aforementioned tribes are species-poor, geographically restricted and perhaps monophyletic. The last, the exclusively subterranean tribe of Brachycerinae, Raymondionymini, is, however, much larger in the number of species, widely distributed and questionably monophyletic.

Fifteen genera and 90 species were listed in Raymondionymini by Morrone \& HLAVÁČ (2018). Most of their diversity centers on the circum-Mediterranean area (Fig. 3 ). In the area delimited by Belgium, the Caspian Sea, Algeria and Portugal the following nine endemic genera (60\% of the tribe) and 74 species (82\%) are naturally distributed: Alaocephala Ganglbauer, 1906 (1 sp.), Alaocyba Perris, 1869 (10 spp., Fig. 4), Coiffaitiella Osella, 1977 (6 spp.), Derosasius Ganglbauer, 1906 (1 sp.), Ferreria Alonso-Zarazaga \& Lyal, 1999 (2 spp.), Raymondiellus Ganglbauer, 1906 (15 spp., Fig. 4), Raymondionymus Wollaston, 1873 (27 spp.), Tarattostichus Ganglbauer, 1906 (2 spp.) and Ubychia Rost, 1893 (10 spp.). Mediterranean Raymondionymini include the type genus (Ferreria, replacement name for Raymondionymus Ganglbauer, 1906), have at least one potential morphological synapomorphy (6-segmented antennal funicle, Fig. 5A; perhaps also the peculiarly shaped tibiae, Fig. 5C) and likely form the monophyletic core of the tribe (OsELLA 1977, Grebennikov 2010). Monophyly of Raymondionymini as a whole is, however, threatened by inclusion of likely only distantly related non-Mediterranean members. 


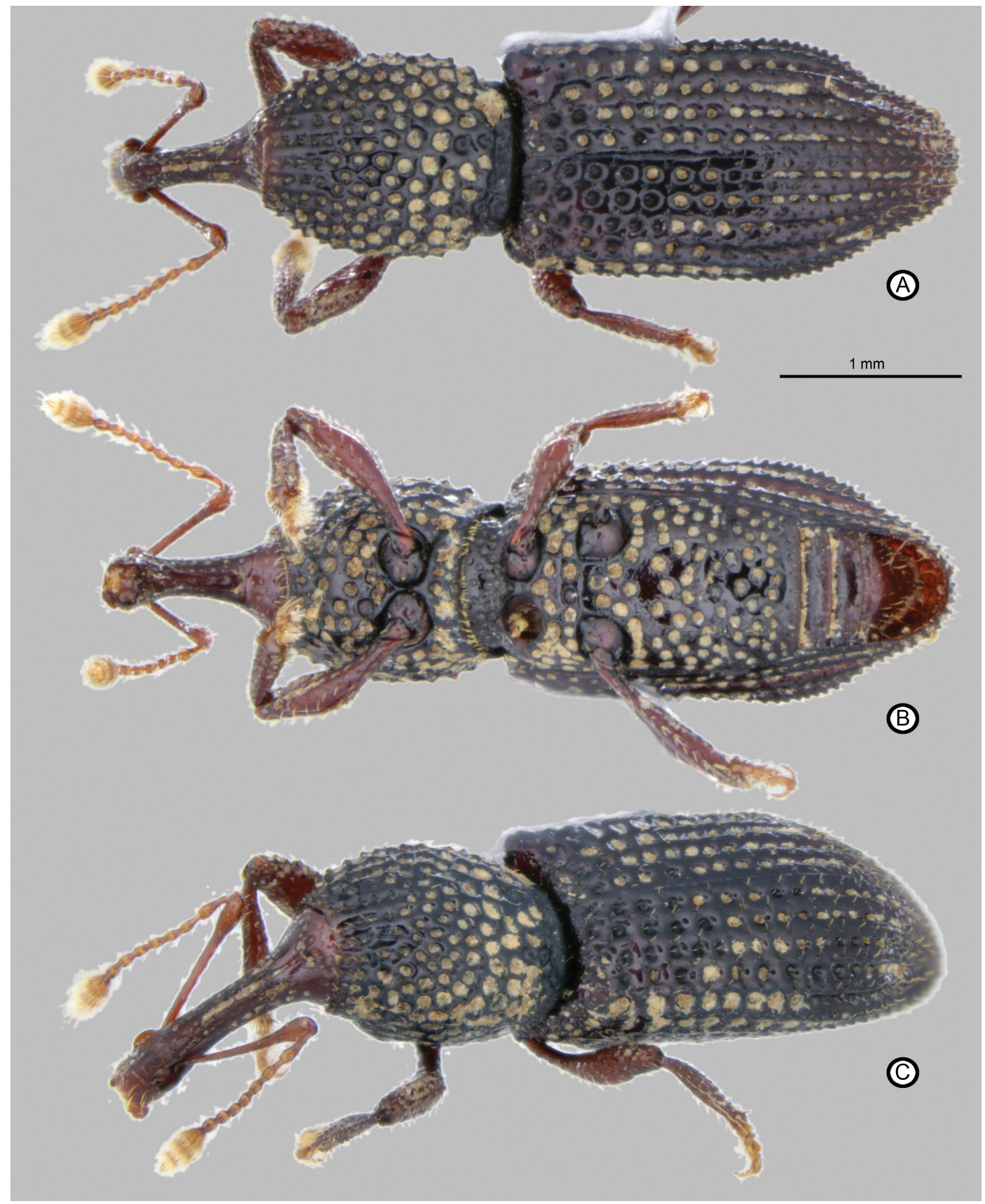

Fig. 1. Yagder serratus gen. \& sp. nov., habitus, dorsal (A), ventral (B) and left fronto-lateral (C).

The non-Mediterranean remainder of Raymondionymini has a spotty global distribution. The state of California in the USA harbours three genera of Raymondionymini, two of them endemic to the state: Gilbertiola Osella, 1982 (2 spp.) and Schizomicrus Casey, 1905 (1 sp., Fig. 4). The third Californian genus, Alaocybites Gilbert,
1956 (with doubtful affinities to the tribe, GREBENNIKov 2010), has two species endemic to California, two others endemic to the Russian Far East (Fig. 4), plus an unnamed late Pliocene fossil from Alaska. Remaining Raymondionymini are known only from their type series. Mexico has the monotypic Neoubychia Gilbert \& Howden, 1987 and 

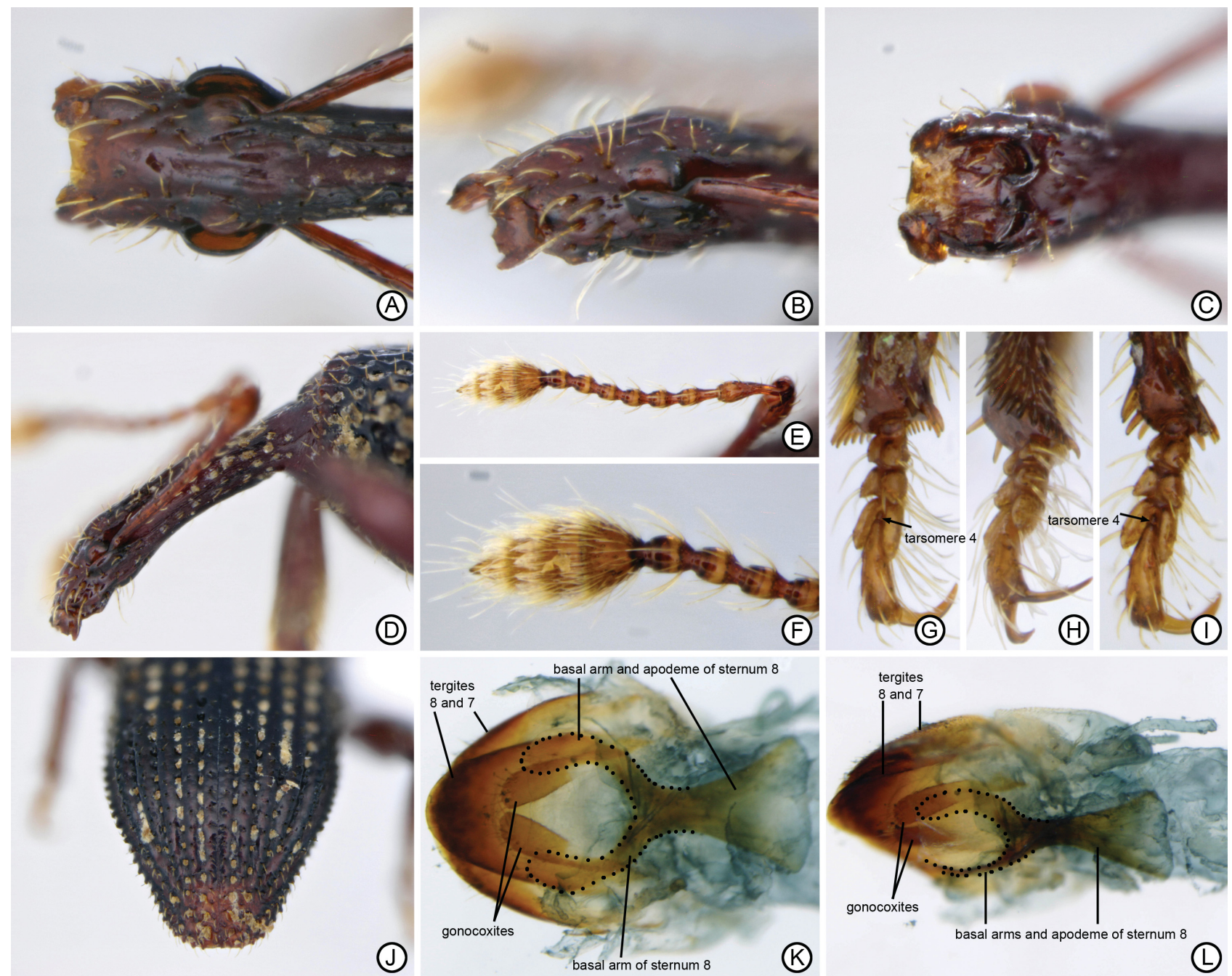

Fig. 2. Yagder serratus gen. \& sp. nov., details. A-C - rostral apex, dorsal (A), left lateral (B), ventral (C); D - head, left lateral; E-F - left antenna, lateral (E), distal part magnified (F); G-I - tarsi, left front leg $(\mathrm{G}-\mathrm{H})$, left middle leg (I); J-elytral apex; K-L-dissected female abdominal apex, ventral $(\mathrm{K})$ and right latero-ventral $(\mathrm{L})$.

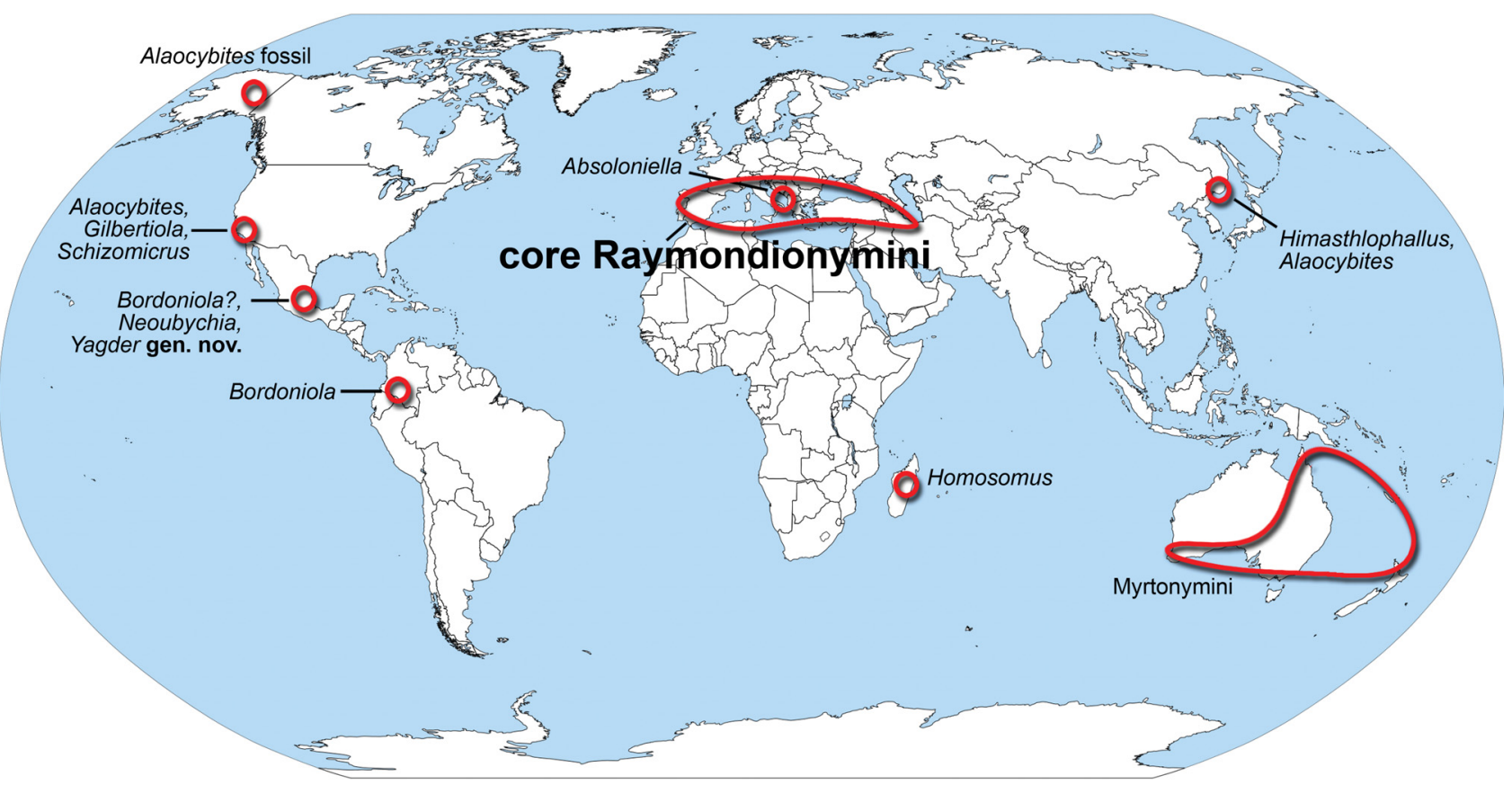

Fig. 3. Distribution of eyeless and nearly eyeless brachycerine weevils. 
Ecuador and Venezuela support seven species of Bordoniola Osella, 1987 (Baviera et al. 2012). Madagascar has three species of Homosomus Richard, 1956 (Figs 4, 5B). Each of these small non-Mediterranean genera appear monophyletic. Most intriguingly, besides their overall body similarity likely brought about by their shared subterranean habits, no convincing evidence suggests that they are most closely related to each other and to the

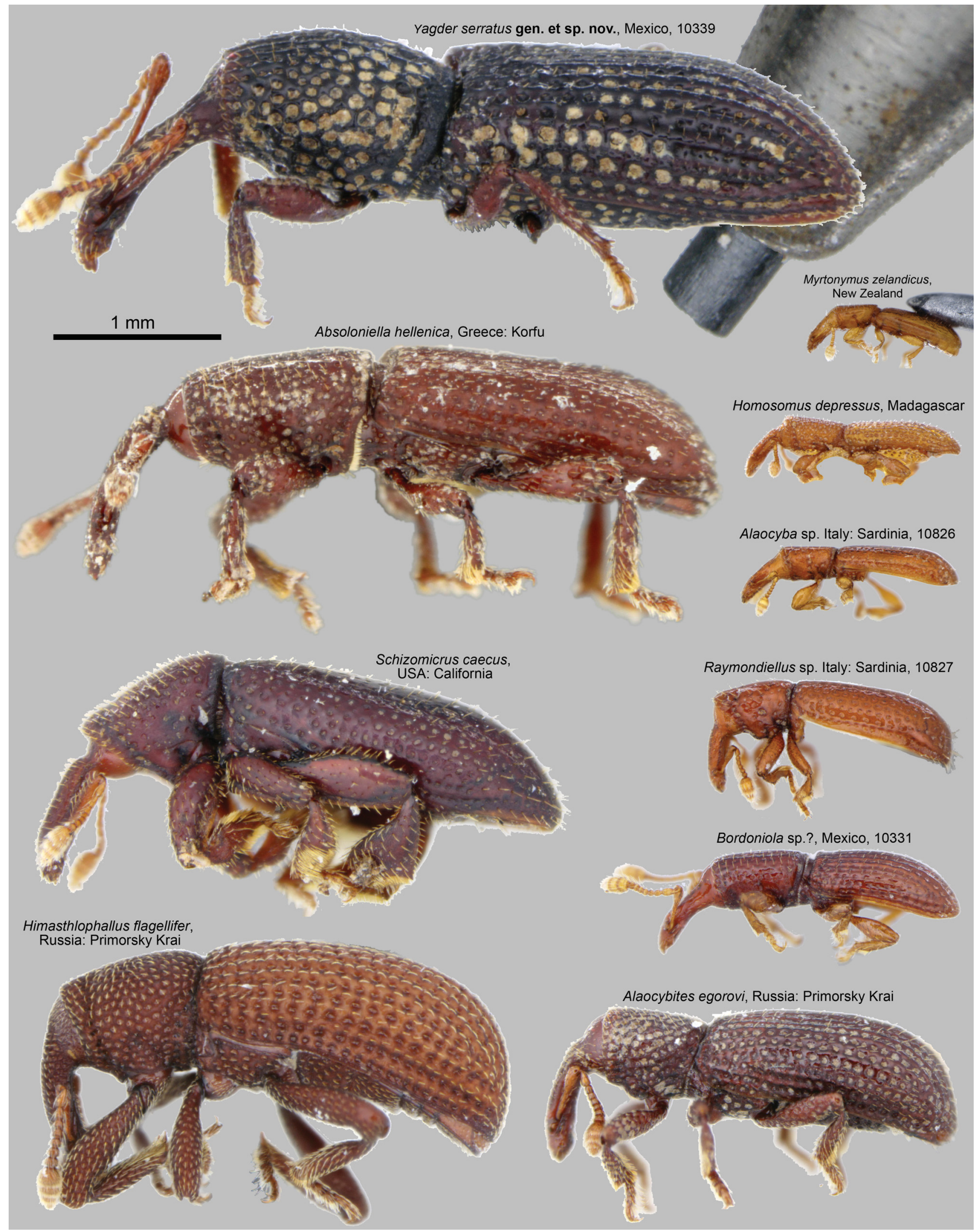

Fig. 4. Eyeless and nearly eyeless brachycerine weevils, habitus. A tip of a regular mechanical pencil with a $0.5 \mathrm{~mm}$ lead is added for size comparison. All images are to scale. 


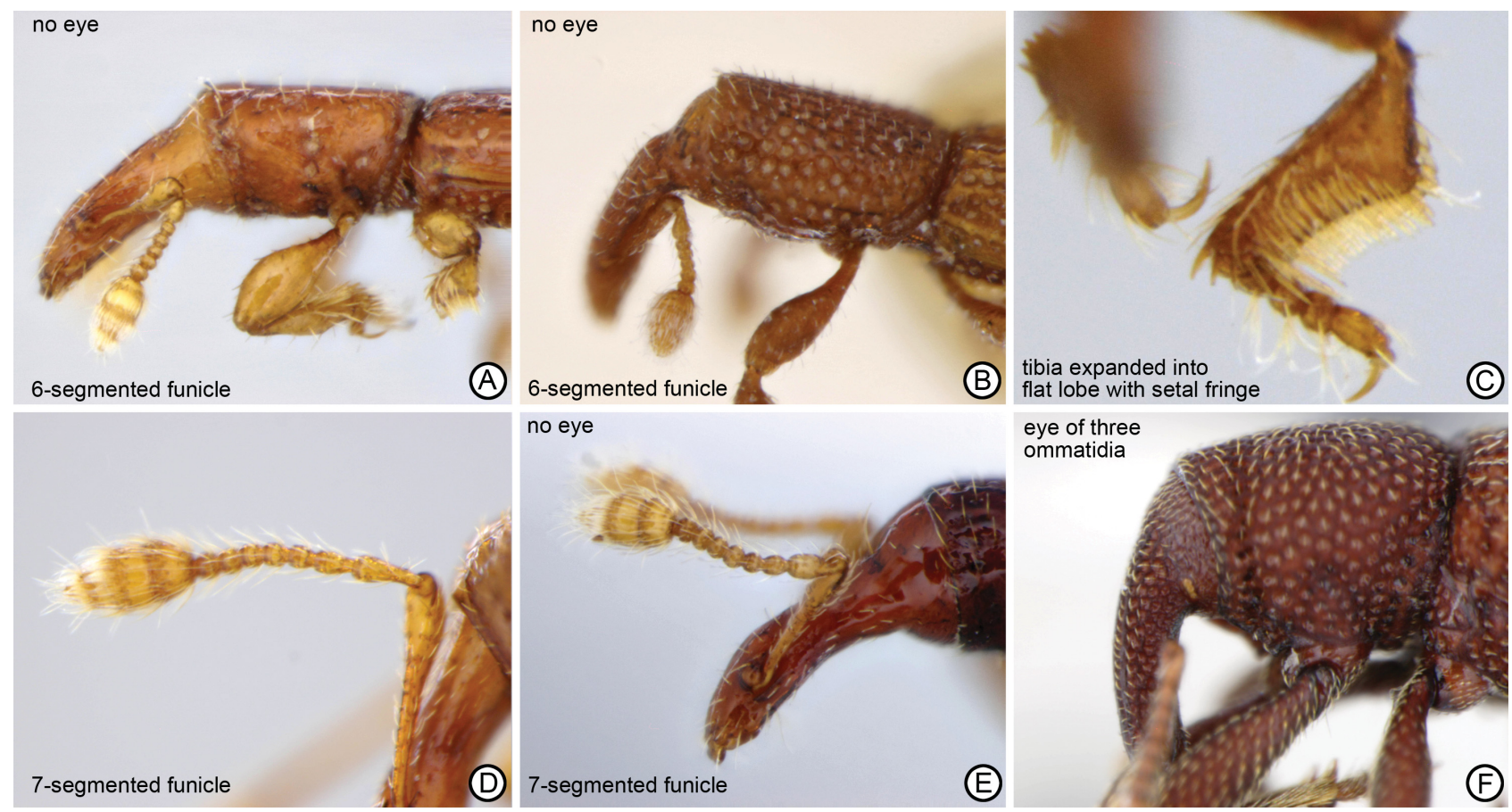

Fig. 5. Eyeless and nearly eyeless brachycerine weevils, details. A - Alaocyba sp. (10826), anterior body, left lateral; B - Homosomus depressus Richard, 1979, anterior body, left lateral; C-Raymondiellus sp. (10827), left middle leg, anterior; D - Bordoniola sp. (10330), left antenna, lateral; E - Bordoniola sp. (10331), head, left lateral; F - Himasthlophallus flagellifer Egorov \& Zherikhin, 1991, anterior body, left lateral.

Mediterranean core of the tribe. These extremely small and cryptic organisms are rarely sampled and, therefore, are acutely understudied.

Rarity of DNA-grade specimens of these eyeless subterranean Brachycerinae conspicuously correlates with their absence in the majority of the recent weevil-wide phylogenetic analyses. Available phylogenetic evidence is, therefore, scarce and inconclusive. Among all of Brachycerinae, only Raymondionymini were a focus of an inconclusive morphology-based phylogenetic analysis (GREBENNIKov 2010). If the tribe is monophyletic, its sister (with or without Myrtonymini and/or Alaocybites) is equally obscure, and so are those of other eyeless Brachycerinae. The only two marginally relevant DNA-based attempts were all-weevil analyses recovering the morphologically aberrant Schizomicrus from California (which is, however, “...not possessing proper pedotectal genitalia...", GUNTER et al. 2016) either as sister to Brachycerus Olivier, 1789 (McKenNA et al. 2009) or to Ocladius (SHIN et al. 2017). Jordal et al. (2011) included Himasthlophallus in an outgroup when addressing wood boring weevils and the origin of subsociality. Although phylogenetically inconclusive with respect to eyeless Brachycerinae, these studies generated relevant genetic data on these rarely seen organisms (Table 1).

Having faced all these uncertainties, we designed two main objectives for our study. Firstly, we describe and introduce to science a new taxon for the blind Mexican weevil. Secondly, we document our attempts at placing this organism into the weevil phylogenetic framework, particularly with respect to the non-monophyletic Brachycerinae. In doing so, we find ourselves severely limited by the lack of any pre-existing phylogenetic hypothesis and even more so by the shortage of relevant DNA data, particularly on the difficult-to-find eyeless Brachycerinae. After having assessed our analytical limitations, we put to a formal test (POPPER 1959) the following hypotheses:

1. The new eyeless Mexican weevil specimen taxonomically belongs to the non-monophyletic Brachycerinae (does not belong to any of the well-established clades of true weevils, particularly those known to contain eyeless species, such as Dryophthorinae, the CEGH clade and the CCCMS clade).

2. Available data are sufficient to place our new eyeless Mexican weevil in a well-supported sister relationship.

3. The Mediterranean core of the tribe Raymondionymini is monophyletic.

4. If so, then at least one non-Mediterranean member of Raymondionymini is/are sister to its Mediterranean core.

5. Eyeless Brachycerinae form a clade (which would imply a single and non-reversed eye reduction and disappearance).

6. None of the weevils currently assigned to Brachycerinae is nested within the main and well-supported weevil radiation delimited by as the least inclusive clade uniting any member of Dryophthorinae and any member of 'higher' Curculionidae (SHIN et al. 2017).

\section{Material and methods}

Composition of the in- and outgroups. The ingroup of the herein implemented analysis was formed by the new Mexican weevil, plus 12 terminals of other Brachycerinae (Table 1, Fig. 6). Two tribes of eyeless (or nearly eyeless) 
Table 1. DNA fragments and their GenBank accession numbers of 41 specimens used for an analysis assess phylogenetic placement of eyelesss Yagder serratus gen. \& sp. nov. in true weevils (Curculionidae), specifically among non-monophyletic Brachycerinae. GenBank accession numbers in bold are those newly sequenced for this analysis; those in regular font are those from our previous studies; those in italics are GenBank sequences of other authors. Two chimera terminals were formed by sequences of different and conspecific specimens (Tanysphyrus lemnae (Paykull, 1792)) or different and congeneric species (Lissorhoptrus LeConte, 1876), thus the total terminal number is 39.

\begin{tabular}{|c|c|c|c|c|c|c|c|c|}
\hline Subfamily & Code & Genus & Species & Voucher & Country & COI & ITS2 & $28 \mathrm{~S}$ \\
\hline Brentinae & Brent & Cylas & formicarius & BTOLDDM0533 & $?$ & FJ867849.1 & none & FJ867676.1 \\
\hline Brachycerinae & & Yagder & serratus & CNCCOLVG00010339 & Mexico & MW201355 & MW201457 & MW201468 \\
\hline Brachycerinae & Brach_Raym1 & Schizomicrus & caecus & BTOLDDM0509 & USA & FJ867824.1 & none & FJ867709.1 \\
\hline Brachycerinae & Brach_Raym2 & Bordoniola & & CNCCOLVG00010330 & Mexico & MW201357 & MW201458 & MW201470 \\
\hline Brachycerinae & Brach_Raym3 & Bordoniola & & CNCCOLVG00010331 & Mexico & MW201361 & MW201461 & MW201474 \\
\hline Brachycerinae & Brach_Raym4 & Bordoniola & & CNCCOLVG00010332 & Mexico & MW201360 & MW201460 & MW201473 \\
\hline Brachycerinae & Brach_Raym5 & Alaocyba & & CNCCOLVG00010826 & Italy & MW201354 & MW201455 & MW201466 \\
\hline Brachycerinae & Brach_Raym6 & Raymondiellus & & CNCCOLVG00010827 & Italy & MW201353 & MW201454 & MW201465 \\
\hline Brachycerinae & Brach1 & Himasthlophallus & flagellifer & ErHim01 & Russia & HQ883654.1 & none & HQ883569.1 \\
\hline Brachycerinae & Brach2 & Ocladius & & BTOLDDM0537 & $?$ & FJ867815.1 & none & FJ867696.1 \\
\hline Brachycerinae & Brach3 & Lissorhoptrus & & BTOLDDM0503 & $?$ & none & none & FJ867689.1 \\
\hline Brachycerinae & Brach4 & Lissorhoptrus & kuscheli & USNM:ENT:01453185 & $?$ & $M N 344695.1$ & none & none \\
\hline Brachycerinae & Brach5 & Tanysphyrus & lemnae & BTOLDDM0507 & $?$ & none & none & FJ867720.1 \\
\hline Brachycerinae & Brach6 & Tanysphyrus & lemnae & GBOL_Col_FK_6085 & $?$ & KM443047.1 & none & none \\
\hline Brachycerinae & Brach7 & Notaris & scirpi & CNCCOLVG00008489 & Poland & KR736279 & MW201453 & MW201464 \\
\hline Brachycerinae & Brach8 & Tournotaris & bimaculata & CNCCOLVG00008578 & Poland & KR736283 & MW201456 & MW201467 \\
\hline Dryophthorinae & Dryop1 & Sphenophorus & parumpunctatus & CNCCOLVG00000434 & Morocco & HM417724 & KY110320 & KY110384 \\
\hline Dryophthorinae & Dryop2 & Sitophilus & zeamais & CNCCOLVG00002735 & China & KJ672255 & MG968837 & MG968894 \\
\hline Dryophthorinae & Dryop3 & Dryophthorus & $\mathrm{n} / \mathrm{a}$ & CNCCOLVG00003561 & Tanzania & MG968913 & MG968814 & MG968871 \\
\hline Dryophthorinae & Dryop4 & Nephius & $\operatorname{argus}$ & CNCCOLVG00004402 & Vietnam & MH034380 & MH034354 & MH034411 \\
\hline Dryophthorinae & Dryop5 & Allaeotes & niger & CNCCOLVG00009972 & Cuba & MN621866 & MN621859 & MN621862 \\
\hline Entiminae & CEGH1 & Prothrombosternus & tarsalis & CNCCOLVG00003280 & Tanzania & KU748541 & KY110337 & KY110402 \\
\hline Entiminae & $\mathrm{CEGH} 2$ & Catapionus & fossulatus & CNCCOLVG00007318 & Russia & KU748528 & KY110302 & KY110364 \\
\hline Entiminae & CEGH3 & Graptus & triguttatus & CNCCOLVG00008909 & Czech Rep. & KY110616 & KY110330 & KY110395 \\
\hline Entiminae & CEGH4 & Nastus & & CNCCOLVG00009056 & Kazakhstan & KY110618 & KY110334 & KY110399 \\
\hline Hyperinae & CEGH5 & Hypera & & CNCCOLVG00009750 & Kazakhstan & MW201362 & MW201462 & MW201475 \\
\hline Entiminae & CEGH6 & Sitona & & CNCCOLVG00010325 & Canada & MW201359 & MW201459 & MW201472 \\
\hline Cossoninae & CCCMS1 & Himatium & & CNCCOLVG00001678 & Tanzania & JN265954 & KY110323 & KY110388 \\
\hline Molytinae & CCCMS2 & Aater & cangshanensis & CNCCOLVG00002676 & China & MG648761 & MG648835 & MG648747 \\
\hline Molytinae & CCCMS3 & Niphadomimus & maia & CNCCOLVG00002731 & China & KJ427744 & KY110324 & KY110389 \\
\hline Cossoninae & CCCMS4 & Carphonotus & testaceus & CNCCOLVG00002970 & Canada & KY110606 & KY110309 & KY110371 \\
\hline Molytinae & CCCMS5 & Devernodes & chthonia & CNCCOLVG00004339 & China & MH034400 & МH034364 & MH034421 \\
\hline Molytinae & CCCMS6 & Adexius & scrobipennis & CNCCOLVG00005848 & Poland & KJ445686 & KY110305 & KY110367 \\
\hline Molytinae & CCCMS7 & Euthycus & & CNCCOLVG00006683 & Taiwan & KJ445702 & KY110325 & KY110390 \\
\hline Molytinae & CCCMS8 & Typoderus & antennarious & CNCCOLVG00007166 & Tanzania & KY250487 & KY250484 & KY250479 \\
\hline Molytinae & CCCMS9 & Cryptorhynchus & lapathi & CNCCOLVG00007530 & Russia & KY110605 & KY110303 & KY110365 \\
\hline Molytinae & CCCMS10 & Niphades & verrucosus & CNCCOLVG00007531 & Russia & KY110610 & KY110314 & KY110376 \\
\hline Molytinae & CCCMS11 & Lepyrus & palustris & CNCCOLVG00008474 & Poland & KX360483 & KY110332 & KY110397 \\
\hline Molytinae & CCCMS12 & Acicnemis & albofasciata & CNCCOLVG00008936 & Russia & KY110609 & KY110312 & KY110374 \\
\hline Molytinae & CCCMS13 & Paranchonus & verrucosus & CNCCOLVG00009809 & Guadeloupe & MW201356 & none & MW201469 \\
\hline Molytinae & CCCMS14 & Dufauiella & heterorostris & CNCCOLVG00009812 & Guadeloupe & MW201358 & none & MW201471 \\
\hline
\end{tabular}

Table 2. DNA fragments used in phylogenetic analysis (total number of sequenced terminals, followed by minimal, maximal and aligned length of each fragment, and the first and the last position of each aligned fragment in the concatenated matrix).

\begin{tabular}{llllll}
\hline Gene & $\#$ & $\min$ & $\max$ & aligned & positions \\
\hline COI-5P & 39 & 453 & 658 & 658 & 1 to 658 \\
ITS2 & 31 & 363 & 636 & 1346 & 659 to 2004 \\
$28 \mathrm{~S}$ & 39 & 436 & 584 & 675 & 2005 to 2679 \\
\hline
\end{tabular}

Brachycerinae were represented. The tribe Raymondionymini was represented by two European genera (Alaocyba and Raymondiellus), by Californian Schizomicrus, and by three terminals from Mexico (specimens 10330-2, Figs 4, $5 \mathrm{D}, \mathrm{E})$ tentatively assigned to the genus Bordoniola. The tribe Himasthlophallini was represented by its single species from the Russian Far East. Eyeless Mytronymini and Erirhinini (Absoloniella) were not represented due to the lack of DNA data. Eyed Brachycerinae were represented by five terminals; two of them were 'chimeras' (Table 1) composed from different DNA fragments of two closely related organisms (either conspecific, or congeneric). The outgroup was composed of 25 terminals (Table 1, Fig. 6) representing three remaining non-Brachycerinae clades of weevils: Dryophthorinae (5 terminals), the CEGH clade (6 terminals) and the CCCMS clade (14 terminals). To root the topology, we added a single representative of Brentidae, the sister family of Curculionidae.

DNA sequencing. To construct the matrix, the following three DNA fragments were used (Table 2, fragment 
abbreviations are in brackets): mitochondrial cytochrome c oxidase I (COI); nuclear internal transcribed spacer 2 (ITS2) and nuclear 28S ribosomal DNA (28S). Three different sources of DNA data were used (Table 1): (I.) 32 newly sequenced fragments with their GenBank accession numbers MW201353-62 and MW201453-73, (II.) our previously released DNA data and (III.) 12 sequences generated by other authors and deposited in GenBank. The latter are those of McKennA et al. (2009), HENDrich et al. (2015) and Jordal et al. (2011). We sequenced DNA at the Canadian Centre for DNA Barcode using their standard protocols (CCDB, http://ccdb.ca/), while our primers are listed in Table 2 in GreBENNIKov (2017). All details pertaining to our lab work (such as DNA extraction, amplification, PCR protocols), as well as images of the original electropherograms, habitus images and locality data for all 32 specimens sequenced by us (Table 1, voucher codes starting with CNCCOLVG000) are available online in the Barcode of Life Database (BOLD, RATNASINGHAM \& HERBERT 2007) public dataset at dx.doi.org/10.5883/DS-VGDS16.

Sequence alignment and phylogenetic analysis. Alignment of all three DNA fragments was done separately using the online MAFFT Q-INS-i algorithm (КАTOH et al. 2017; https://mafft.cbrc.jp/alignment/server/). We trimmed the extending 3 '-end of one COI and of six $28 \mathrm{~S}$ fragments sequenced by others (Table 1). No internal parts of DNA fragments were removed prior to the analysis, even if parts of the alignments consisted mainly of insertions/deletions (indels). Three aligned single-fragment datasets were concatenated using Mesquite 3.61 (MADDISON \& MADDISON 2020) into a matrix of 2679 positions and containing $40 \%$ of the completely undetermined characters (mainly due to ITS2 sequences absent for eights terminals and numerous indels in the remaining ITS2 sequences, Table 2). An unrooted topology was built using a Maximum Likelihood (ML) approach, as implemented in CIPRES Science Gateway online platform (MILLER et al. 2010; http://www.phylo. org/, tool 'RAxML-HPC2 on XSEDE') and using RAxML 8 (STAMATAKIs 2014) algorithm. We applied CAT approximation to the widely used GTR + G nucleotide substitution model independently for each of three partitions. Support values were obtained based on 1000 bootstrap replicates (STAMATAKIS et al. 2008). The tree was visualized in FigTree v1.4.4. (RAmbaut 2020).

Morphological methods. The single specimen of the new species (Figs 1-2) was first imaged in toto and then softened in warm water for dissection. Its abdomen was macerated in a warm water solution of potassium hydroxide and disarticulated to extract and illustrate internal structures (Figs 2K, L). Chlorazol Black was used to stain internal membranes in light blue (Figs 2K, L). Adult weevil morphological terms are those of LYAL (2020).

\section{Results}

The Maximum Likelihood analysis resulted in a moderately resolved tree (Fig. 6). The new eyeless Mexican weevil (marked with red arrow in Fig. 6) lacked a well- -supported sister-group and was recovered outside the Dryophthorinae, CEGH or CCCMS clades. The clade of Dryophthorinae was taxonomically coherent and moderately supported (bootstrap 86\%). The molytine genus Devernodes Grebennikov, 2018, taxonomically a member of the CCCMS clade, formed, however a weakly supported clade with two Brachycerinae genera; all three of them were in a weakly supported relationship with a weakly supported clade formed by the rest of the CCCMS clade and the CEGH clade. The CEGH clade and the CCCMS clade (without Devernodes) were both strongly supported ( $92 \%$ and $91 \%$, respectively). Brachycerinae were non-monophyletic, forming the family's 'twilight zone'. Both European Raymondionymini formed a strongly supported clade $(100 \%)$ distantly related to the two other tribe's members, the genera Schizomicrus and Bordoniola (Fig. 6); the latter two not forming a clade.

\section{Yagder gen. nov.}

Type species. Yagder serratus sp. nov., here designated. Diagnosis. This genus can be recognized among all weevils (Curculionoidea, including true weevils Curculionidae) by the combination of the following characters: eye completely absent; body size larger, $3.8 \mathrm{~mm}$ in length (excluding rostrum and deeply inserted head), slender (ratio of length to maximal width 2.9) and parallel-sided in dorsal view; rostrum almost as long as pronotum, with deep median longitudinal furrow throughout greater portion of length both dorsally and ventrally; pronotum and elytra with large, deep round punctures, those on anterior portion of pronotum smaller, somewhat coalescent, forming striae; elytra with eight complete striae, five visible in dorsal view, strial punctures on elytra large basally, smaller towards elytral apex; tibial apices with short, stout spines, spines greatest in number and most closely spaced on front tibia; elytra with humeral angle sharp, produced anteriorly; female genitalia with gonocoxites flat, spade-like, lacking stylus, sternum 8 Y-shaped, with arms arcuate, apodeme short, broad, apically expanded.

Description. Body $3.8 \mathrm{~mm}$ in length (excluding rostrum and deeply inserted head), slender (ratio of length to maximal width 2.9) and parallel-sided in dorsal view; prothorax, elytra, meso- and metaventrites and two visible basal abdominal ventrites with deep round punctures, many of them accumulating fine soil particles; body and all appendages uniformly dark-brown; without dense pilosity; with short and sparse erect setae. Head capsule deeply retracted into pronotum, almost invisible in dorsal view; eye completely absent. Rostrum in lateral view about 0.9 times as long as pronotum in dorsal view; narrowest at mid-length; with deep longitudinal furrow along mid-line dorsally and ventrally; with antennae attached in apical third; with pterygia at points of antennal insertions exposed in dorsal view, scrobes shallow, not visible in dorsal view, directed posteriorly to middle of head. Antennae geniculate, with funicle and club consisting of seven and three antennomeres, respectively; scape about subequal in length to funicle. Prothorax without postocular lobes; procoxae subcontiguous; hypomeral lobes about $60 \%$ as long as 


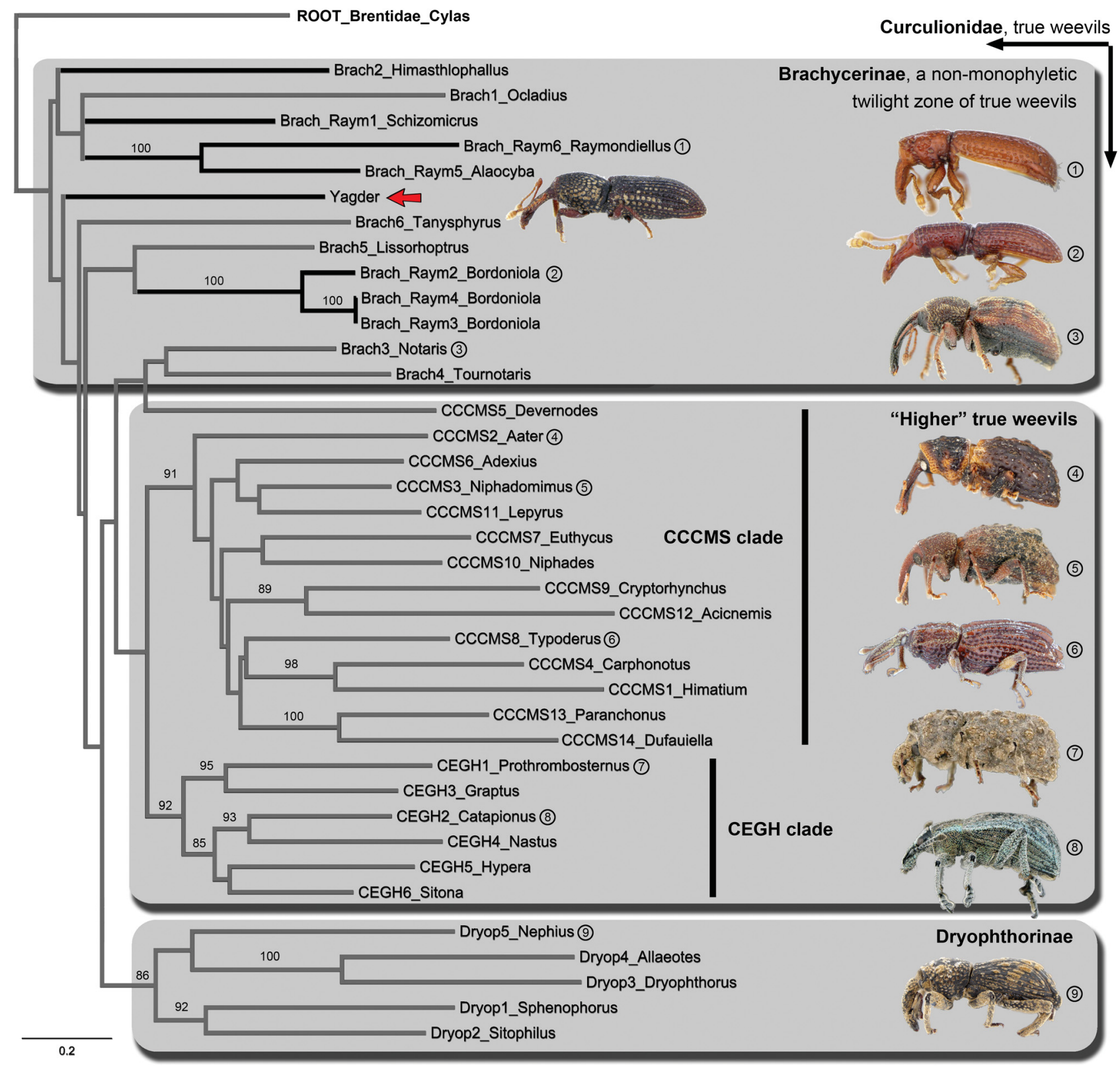

Fig. 6. Maximum Likelihood inference phylogram positioning Yagder serratus gen. \& sp. within non-monophyletic Brachycerinae. Note non-monophyly of Raymondionymini. Black lines denote eyeless or nearly eyeless terminals and clades. Digits at internodes are bootstrap values $>85 \%$.

procoxal cavities; pronotum evenly rounded in dorsal view, without delimited disk, in anterior third with 5-6 fine striae each accommodating 3-5 smaller punctures arranged in longitudinally oriented lines, in posterior half with much larger punctures forming an irregular cross-pattern. Mesoand metathorax with minute scutellum visible externally; hind wings (if present) not examined; mesocoxae separated by about one-third of their individual diameter; metacoxae separated by about their individual diameter. Elytra with humeral angles sharp, slightly produced anteriorly; with eight complete striae, five visible in dorsal view, strial punctures very large in basal one-half of elytral length, decreasing in size in apical portion of length, those on striae 8 very small, shallow throughout length. Abdomen with ventrites I and II subequal in length laterally, densely deeply punctate, III and IV much shorter, combined length shorter than length of ventrite II, impunctate, ventrite V impunctate, about as long as III and IV combined. Legs without femoral teeth; tibial apices with only rows of short, stout spines, spines greatest in number and most closely spaced on front tibia (Figs. 2G-I), without tooth-like process potentially homologous to mucro, pre-mucro or uncus; femora without groove in basal half to receive tibiae; tibiae without flat lobes with setal fringes; tarsomere IV present, small and hidden between lobes of tarsomere III (Figs 2H, I); claws simple, large, widely divergent. Female genitalia with spiculum ventrale (= internal apodeme of sternum 8) consisting of two weakly sclerotized arcuate basal arms and short, broad, apically expanded apodeme of nearly equilateral triangular shape (Figs $2 \mathrm{~K}, \mathrm{~L}$ ); each gonocoxite (= part of sternum 9, "coxite-stylus") posteriorly rounded and setose, spade-like, well-sclerotized, lacking stylus 
(Figs 2K, L); sclerotized spermatheca not detected. Male genitalia unknown.

Species composition and distribution. The genus is monotypic and its known distribution is limited to the type locality of its only species (see below).

Etymology. The generic name is a meaningless combination of letters; its gender is masculine.

Note. Males will be expected to have a pedotectal type of genitalia that is typical for Brachycerinae.

\section{Yagder serratus sp. nov.}

(Figs 1, 2, 4, 6)

Type locality. Mexico, Puebla, 5 km SW Hueytamalco, N $19.911^{\circ} \mathrm{W}$ $97.328^{\circ}, 1370 \mathrm{~m}$ a.s. 1

Material examined. HoLOTYPE: female, 'MEXICO, Puebla, 19.911 -97.328, 1370m, 13.vi.2019, sift., J.Longino 10670', 'CNCCOLVG00010339' (deposited in the Canadian Museum of Nature, Ottawa, Canada). The holotype is missing both hind legs (one used for sequencing), the right middle leg and right front tarsus.

Description. Body size large, $3.8 \mathrm{~mm}$ in length (excluding rostrum and deeply inserted head). Rostrum with pterygia very widely exposed in dorsal view (Fig. 2A), apical two antennomeres of funicle longer than wide (Fig. 1C). Pronotal and elytral contour in dorsal view with large saw-like serrations especially evident towards elytral apex (Fig. 2J). Abdomen with ventrites I and II densely deeply punctate. DNA: MW201355 (COI), MW201457 (ITS2) and MW201468 (28S).

Biology. A single female was sifted from leaf litter in primary mountain forest. Multiple samples taken at the same time and location by J. T. Longino and M. G. Branstetter failed to produce additional specimens.

Etymology. The species name is the Latin adjective meaning "serrated, toothed like a saw".

Distribution. This species is known only from the type locality.

\section{Discussion}

Our topology (Fig. 6), although based on only three DNA markers, agrees well with that of SHIN et al. (2017) in all its most important aspects. The latter, however, was based on a $>150$ times greater dataset from 522 protein-coding genes. Our most significant deviation from SHIN et al. (2017) and other comparably detailed DNA-based studies of weevil phylogeny (listed in Introduction) is the recovery of the Molytinae genus Devernodes outside the CCCMS clade and in a weakly supported and seemingly odd clade together with the Brachycerinae genera Notaris Germar, 1817 and Tournotaris Alonso-Zarazaga \& Lyal, 1999 (Fig. 6). We treat this aberrant clade partly as a random artifact of our analysis, and partly as a reflection of the documented tendency of the genus Devernodes to form relationships with taxa outside of the CCCMS clade (GrebenNikov 2018, GrebenNiKov \& ANDERSON 2021). Most significantly, all 13 remaining CCCMS terminals formed a strongly supported clade, itself a sister (although weakly supported) to the strongly supported clade uniting all six CEGH terminals (Fig. 6). This combined CCCMC plus CEGH clade of 'higher' weevils corresponds to a more narrowly defined family Curculionidae sensu THOMPSON (1992) and is supported by the classical weevil morphological synapomorphy of the pedal type of male genitalia. Recovery in our analysis of the CCCMS + CEGH clade is consistent with earlier morphological and molecular results and, therefore, suggestive of the overall credibility of our topology (Fig. 6).

Disregarding the odd clade of Devernodes and two other genera (see above), interpretation of the herein presented results leads us to conclude that:

Prediction 1 (Yagder serratus gen. \& sp. nov. belongs to a non-monophyletic Brachycerinae) is supported, because this beetle was recovered on our tree (Fig. 6) outside of the monophyletic core of the family Curculionidae formed by the least inclusive clade uniting any member of Dryophthorinae and any member of 'higher'Curculionidae (SHIN et al. 2017).

Prediction 2 (available data are sufficient to place our new eyeless Mexican weevil in a well-supported sister relationships) is rejected, because the recovered sister-group placement of Yagder is weakly supported (Fig. 6) and is, therefore unreliable.

Prediction 3 (the Mediterranean core of the tribe Raymondionymini is monophyletic) is supported, because both representative terminals, the genera Alaocyba and Raymondiellus, formed a strongly supported (100\%) clade (Fig. 6).

Prediction 4 (at least one non-Mediterranean member of Raymondionymini is sister to its Mediterranean core) cannot be adequately tested, because the monophyletic Mediterranean core of the tribe is a part of an unresolved and weakly supported polytomy including also Schizomicrus and Ocladius (Fig. 6).

Prediction 5 (eyeless Brachycerinae form a clade, implying a single and non-reversed eye reduction and disappearance) is rejected, because the trait of eyelessness (or microphthalmia, as with Himasthlophallus, Fig. 5C) is scattered among five not most closely related clades of Brachycerinae (Fig. 6).

Prediction 6 (none of weevils currently assigned to Brachycerinae is nested within the main weevil radiation delimited as the least inclusive clade uniting any member of Dryophthorinae and any member of 'higher'Curculionidae, SHIN et al. 2017) is supported, on the same ground, as the Prediction 1 (above).

Summing up, our newly described eyeless weevil Yagder serratus gen. \& sp. nov. from Mexico is a member of the twilight zone of true weevils (Curculionidae) taxonomically temporarily designated as the non-monophyletic subfamily Brachycerinae. This subfamily will probably be retained for as long as it takes to reliably resolve the branching pattern between two well-established dichotomies: one separating Curculionidae from its sister group (Brentidae), and another separating the clade of any Dryophthorinae plus any CCCMS/CEGH member from its presently unknown sister group. Once done, the subfamily Brachycerinae will likely be split into two or more species-poor early-divergent subfamilies, one of them potentially the sister to the remainder of all weevils. 
Until then the artificial subfamily Brachycerinae might serve its present utilitarian purpose of temporary housing taxonomically and phylogenetically unresolved weevils not belonging to other better understood and species-rich clades. We, consequently, taxonomically designate the new genus Yagder as Brachycerinae incertae sedis, that is, not included in any tribe of Brachycerinae (at least one of them, Raymondionymini, comparably non-monophyletic).

\section{Concluding remark}

Numerous peculiarities of our discovery of Yagder serratus gen. \& sp. nov. strongly recalls those of the mite Proterorhagia oztotloica Lindquist \& Palacios-Vargas, 1991 (Lindquist \& Palacios-Vargas 1991). In both cases a new species and a new genus were erected based on a single soil-inhabiting specimen from Mexico of strange morphology and unresolved phylogenetic position. In both cases the new organisms were assigned to a non-monophyletic twilight zone of much larger clades: Brachycerinae and Endeostigmata, respectively. The mite genus Proterorhagia is the type genus of the monotypic family Proterorhagiidae. This family is still known from a single specimen and is likely sister to the rest of Acariformes (BOLTON et al. 2017), the latter a hyper-diverse clade of over 32,000 described species and perhaps half a million of undescribed ones. Does Yagder serratus gen. $\&$ sp. nov. occupy a similarly exalted place on the weevil Tree of Life worthy of a family-group name of its own? Only time will tell.

\section{Acknowledgements}

John T. (Jack) Longino (Salt Lake City, USA) collected the only existing specimen of the new genus although he and Michael G. Branstetter took multiple litter samples at the type locality. Peter Hlaváč (Prague, Czech Republic) made available both specimens of the Old World Raymondionymini (Alaocyba sp. and Raymondiellus sp., specimens 10826 and 10827, respectively, Fig. 4); he and Massimo Meregalli (Torino, Italy) assisted with their identification. Didier Van den Spiegel, curator of Coleoptera in the Musée Royal de 1'Afrique Centrale (Tervuren, Belgium), facilitated a loan of the imaged specimen of Homosomus (Fig. 4); Klaus-Dieter Klass, curator of Coleoptera in the Senckenberg Naturhistorische Sammlungen (Dresden, Germany) did likewise with respect to Absoloniella (Fig. 4). The late Guillermo (Willy) Kuschel (Auckland, New Zealand) sent us the imaged specimen of Myrtonymus (Fig. 4).

\section{References}

BAI M., BEUTEL R. G., KLASS K. D., ZHANG W., YANG X. \& WIPFLER B. 2016: †Alienoptera-A new insect order in the roachmantodean twilight zone. Gondwana Research 39: 317-326.

BAVIERA C., BELLÒ C. \& OSELLA G. 2012: First record of the genus Bordoniola Osella, 1987 in Ecuador with description of five new species (Coleoptera: Curculionidae, Raymondionyminae). Zootaxa 3455: 69-80.

BOLTON S. J., CHETVERIKOV P. E. \& KLOMPEN H. 2017: Morphological support for a clade comprising two vermiform mite lineages: Eriophyoidea (Acariformes) and Nematalycidae (Acariformes).
Systematic and Applied Acarology 22: 1096-1131.

CALDARA R. \& COLLA A. 2018: A contribution to the knowledge of Absoloniella Formánek, 1913, a Mediterranean genus of blind weevils (Coleoptera, Curculionidae). Atti del Museo Civico di Storia Naturale di Trieste 59: 221-240.

DAVIS S. R. 2017: The weevil rostrum (Coleoptera: Curculionoidea): internal structure and evolutionary trends. Bulletin of the American Museum of Natural History 416: 1-76.

GILLETT C. P. D. T., CRAMPTON-PLATT A., TIMMERMANS M. J. T. N., JORDAL B. H., EMERSON B. C. \& VOGLER A. P. 2014: Bulk de novo mitogenome assembly from pooled total DNA elucidates the phylogeny of weevils (Coleoptera: Curculionoidea). Molecular Biology and Evolution 31: 2223-2237.

GREBENNIKOV V. V. 2010: First Alaocybites weevil (Insecta: Coleoptera: Curculionoidea) from the Eastern Palaearctic: a new microphthalmic species and generic relationships. Arthropod Systematics and Phylogeny 69: 331-365.

GREBENNIKOV V. V. 2017: Phylogeography and sister group of Lupangus, a new genus for three new flightless allopatric forest litter weevils endemic to the Eastern Arc Mountains, Tanzania (Coleoptera: Curculionidae, Molytinae). Fragmenta Entomologica 49: 37-55.

GREBENNIKOV V. V. 2018: Discovery of Lymantini weevils (Coleo= ptera: Curculionidae: Molytinae) outside the Americas: Devernodes, a new genus for five new species from Southeast Asia. Zootaxa 4500: 363-380.

GREBENNIKOV V. V. \& ANDERSON R. S. 2021: Late Miocene eastwards transatlantic dispersal of flightless anchonine weevils (Coleoptera: Curculionidae: Molytinae). Zootaxa 4962: 55-70.

GUNTER N. L., OBERPRIELER R. G. \& CAMERON S. L. 2016 : Molecular phylogenetics of Australian weevils (Coleoptera: Curculionoidea): exploring relationships in a hyperdiverse lineage through comparison of independent analyses. Austral Entomology 55: $217-233$

HARAN J., TIMMERMANS M. J. T. N. \& VOGLER A. P. 2013: Mitogenome sequences stabilize the phylogenetics of weevils (Curculionoidea) and establish the monophyly of larval ectophagy. Molecular Phylogenetics and Evolution 67: 156-166.

HEBERT P. D. N., CYWINSKA A., BALL S. L. \& DEWAARD J. R. 2003: Biological identifications through DNA barcodes. Proceedings of the Royal Society B, Biological Sciences 270: 313-321.

HENDRICH L., MORINIERE J., HASZPRUNAR G., HEBERT P. D. N., HAUSMANN A., KOHLER F. \& BALKE M. 2015: A comprehensive DNA barcode database for Central European beetles with a focus on Germany: Adding more than 3500 identified species in BOLD. Molecular Ecology Resources 15: 795-818.

HERATY J. M., BURKS R. A., CRUAUD A., GIBSON G. A. P., LILJEBLAD J., MUNRO J., RASPLUS J.-Y., DELVARE G., JANŠTA P., GUMOVSKY A., HUBER J. T., WOOLLEY J. B., KROGMANN L., HEYDON S. L., POLASZEK A., SCHMIDT S., DARLING D. C., GATES M. W., MOTTERN J., MURRAY E., MOLIN A. D., TRIAPITSYN S., BAUR H., PINTO J. D., NOORT S. V., GEORGE J. \& YODER M. J. 2013: A phylogenetic analysis of the megadiverse Chalcidoidea (Hymenoptera). Cladistics 29: 466-542.

HOWDEN A.T. 1992: Review of the New World eyeless weevils with uncinate tibiae (Coleoptera, Curculionidae: Molytinae, Cryptorhynchinae, Cossoninae). Memoirs of the Entomological Society of Canada 162: 1-76.

JORDAL B. H., SEQUEIRA A. S. \& COGNATO A. I. 2011: The age and phylogeny of wood boring weevils and the origin of subsociality. Molecular Phylogenetics and Evolution 59: 708-724.

KATOH K., ROZEWICKI J. \& YAMADA K. D. 2017: MAFFT online service: multiple sequence alignment, interactive sequence choice and visualization. Briefings in Bioinformatics 20 (4) [2019]: 1160-1166 (published online first 6 September 2017).

KLIMOV P. B., OCONNOR B. M., CHETVERIKOV P. E., BOLTON S. J., PEPATO A. R., MORTAZAVI A. L., TOLSTIKOV A. V., BAUCHAN G. R. \& OCHOA R. 2018: Comprehensive phylogeny of acariform mites (Acariformes) provides insights on the origin of the four-legged mites (Eriophyoidea), a long branch. Molecular Phylogenetics and Evolution, 119: 105-117. 
KUSCHEL G. 2014:The blind weevils of Myrtonymina in New Caledonia and Australia (Curculionidae: Curculioninae: Erirhinini: Myrtonymina). Pp. 165-180. In: GUILBERT É., ROBILLARD T., JOURDAN H. \& GRANDCOLAS P. (eds): Zoologia Neocaledonica 8. Biodiversity studies in New Caledonia. Muséum National d'Histoire Naturelle, Paris, 315 pp.

LINDQUIST E. E. \& PALACIOS-VARGAS J. G. 1991: Proterorhagiidae (Acari, Endeostigmata), a new family of Rhagidiid-like mites from Mexico. Acarologia 32: 341-363.

LOPARDO L. \& HORMIGA G. 2015: Out of the twilight zone: phylogeny and evolutionary morphology of the orb-weaving spider family Mysmenidae, with a focus on spinneret spigot morphology in symphytognathoids (Araneae, Araneoidea). Zoological Journal of the Linnean Society 173: 527-786.

LYAL C. H. C. 2020: Glossary of Weevil Characters. International Weevil Community Website. Permanent publication available from: http:// weevil.info/glossary-weevil-characters (accessed 3 November 2020).

MADDISON W. P. \& MADDISON D. R. 2020: Mesquite: a modular system for evolutionary analysis. Version 3.5. Software and documentation. Available from: http://mesquiteproject.org (accessed 10 July 2020)

MARVALDI A. E., SEQUEIRA A. S., O’BRIEN C. W. \& FARRELL B. D. 2002: Molecular and morphological phylogenetics of weevils (Coleoptera, Curculionoidea): do niche shifts accompany diversification? Systematic Biology 51: 761-785.

MCKENNA D. D., SEQUEIRAA. S., MARVALDI A. E. \& FARRELL B. D. 2009: Temporal lags and overlap in the diversification of weevils and flowering plants. Proceedings of the National Academy of Sciences 106: 7083-7088.

MILLER M., PFEIFFER W. \& SCHWARTZ T. 2010: Creating the CIPRES Science Gateway for inference of large phylogenetic trees. Proceedings of the Gateway Computing Environments Workshop (GCE), New Orleans, Louisiana 2010: 1-8.

MORRONE J. J. \& HLAVÁČ P. 2018: Checklist of the micro- and anophthalmic soil-dwelling weevils of the world (Coleoptera: Curculionidae). Zootaxa 4239: 1-102.
OBERPRIELER R.G. 2016: 3.7.1 Brachycerinae Billberg, 1820. Pp. 424 451. In: LESCHEN R. A. B. \& BEUTEL R. G. (eds): Handbook of Zoology, Arthropoda: Insecta: Coleoptera. Volume 3: Morphology and Systematics (Phytophaga). Walter de Gruyter, Berlin, $675 \mathrm{pp}$.

OBERPRIELER R. G., MARVALDI A. E. \& ANDERSON R. S. 2007: Weevils, weevils, weevils everywhere. Zootaxa 1668: 491-520.

OSELLA G. 1977: Revisione della sottofamiglia Raymondionyminae (Coleoptera, Curculionidae). Memorie del Museo Civico di Storia Naturale di Verona, 2 Serie, Sezione Scienze della Vita 1: 1-162.

OSELLA G. 1979: Soil Curculionidae (Coleoptera). Bolletino di Zoologia 46: 299-318.

POPPER K. 1959: The logic of scientific discovery. Basic Books, New York, 484 pp.

RAMBAUT A. 2020: FigTree. Version 1.4.4. Software and documentation. Available from: http://tree.bio.ed.ac.uk/software/figtree/ (accessed 15 March 2019)

RATNASINGHAM S. \& HEBERT P. D. N. 2007: BOLD: The Barcode of Life Data System (http://www.barcodinglife.org). Molecular Ecology Notes 7: 355-364.

SHIN S., CLARKE D. J., LEMMON A. R., LEMMON E. M., AITKEN A. L., HADDAD S., FARRELL B. D., MARVALDI A. E., OBERPRIELER R. G. \& MCKENNA D. D. 2017: Phylogenomic data yield new and robust insights into the phylogeny and evolution of weevils. Molecular Biology and Evolution 35: 823-836.

STAMATAKIS A. 2014: RAxML version 8: a tool for phylogenetic analysis and post-analysis of large phylogenies. Bioinformatics 30: 1312-1313.

STAMATAKIS A., HOOVER P. \& ROUGEMONT J. 2008: A rapid bootstrap algorithm for the RAxML web servers. Systematic Biology 57: 758-771.

THOMPSON R. T. 1992: Observations on the morphology and classification of weevils (Coleoptera, Curculionoidea) with a key to major groups. Journal of Natural History 264: 835-891. 